\title{
BIOECOLOGY OF Spodoptera frugiperda (Smith, 1757) IN DIFFERENT COVER CROPS
}

\section{BIOECOLOGIA DE Spodoptera frugiperda (Smith, 1757) EM DIFERENTES PLANTAS DE COBERTURA}

\author{
Aline Silvia DIAS ${ }^{1}$; Rosangela Cristina MARUCCI ${ }^{2}$; Simone Martins MENDES $^{3}$; \\ Silvino Guimarães MOREIRA ${ }^{4}$; Octávio Gabriel ARAÚJO' ${ }^{1}$; \\ Christiane Almeida dos SANTOS ${ }^{1}$; Tatiane Aparecida BARBOSA ${ }^{1}$
}

1. Estagiários da Embrapa Milho e Sorgo e estudantes do Centro Universitário de Sete Lagoas, Sete Lagoas, MG, Brasil; 2. Professora, Doutora, Universidade Federal de Lavras, Lavras, MG, Brasil; 3. Pesquisadora Doutora da Embrapa Milho e Sorgo, Sete Lagoas, MG, Brasil. simone.mendes@embrapa.br; 4. Professor, Doutor, Universidade Federal de São João Del-Rei, Sete Lagoas, MG, Brasil.

\begin{abstract}
The objective of this work was to evaluate the biological variables of Spodoptera frugiperda on species of cover crops. The experiments were conducted in laboratory and greenhouse using the following species: sunflower (Helianthus annuus), sun hemp (Crotalaria juncea), brachiaria (Urochloa decumbens e Urochloa ruziziensis), millet (Pennisetum americanum), black oat (Avena stringosa), white lupin (Lupinus albus), forage turnip (Rafanus sativus) and maize (Zea mays). In laboratory the S. frugiperda larval survival varied from 57\%, on L. albus, to 93\% on H. annuus and the survival of the pre-imaginal phase varied from $45 \%$ on $U$. decumbens to $81.6 \%$ on Z. mays. On C. juncea the larval biomass was lower and the development period of the young and larval stage was higher. The adaptation index was less on $C$. juncea in greenhouse and laboratory. In greenhouse the larval survival at 14 days was similar for all plants and at 21 days was the lowest on $C$. juncea. There was less accumulation of biomass at 14 days on $C$. juncea and at 21 days on $C$. junce a and A. stringosa. Regarding damage, $C$. juncea presented less susceptibility to Spodoptera frugiperda attack, which together with the other evaluated parameters, indicated this plant as the most appropriate for soil cover before cultivation of maize.
\end{abstract}

KEYWORDS: Cover crops. Fall armyworm. No-tillage. Zea mays.

\section{INTRODUCTION}

The search for sustainable solutions in agriculture has been stimulated in Brazil (FALEIROS, 2011). In this scenario, we highlight the low-carbon agriculture that aims to reduce greenhouse gas emissions through more sustainable farming practices. The initiative consists of various mitigation techniques such as conservation tillage, which consists in sowing a crop of economic interest on the residue of the previous crop, improving the soil physical, chemical and biological properties (AZIS et al., 2013).

No-tillage it is one way to improve physical, chemical and biological soil conditions. However, if is not properly conducted it can favor increased plant health problems. To secure system maintenance there is a need of cultivating cover crops, which precede the main crop and have physical protection function against soil erosion, germination of weed and soil water loss (BOER et al., 2007).

No-tillage was introduced in southern Brazil in the early 1970s, but underwent greater expansion in the 1990s. According to Sá et al. (2009), this growth is due to the system associating conservation management and low energy cost principles, thus providing a greater financial return. No-tillage has the characteristic of being a management system which avoids tillage, thus creating a new ecological environment, different from that existing in the conventional system. As a result, it has a number of benefits for the farmer and for the environment. Some advantages can be highlighted: erosion control, soil moisture conservation, weed control, improved soil structure and plant health (CRUZ, 1999). Moreover, it can also favor the local biodiversity maintenance, contributing to the persistence of many insects, including potential natural enemies, because the accumulated cover crop residue favors the soil macrofauna communities (MARCHÃO, 2007; SILVA et al., 2007).

According to Alvarenga et al. (2001), to choose the right cover crops, it is necessary to understand the adaptation to the region and the ability to grow in a less favorable environment since the commercial crops are established at more favorable times. One should also take into consideration the phytomass and soil cover productivity (NUNES et al., 2006; ANDRIOLI et al., 2008) and the potential of these plants to be, or not, hosts for pests or diseases (BARROS et al., 2010). 
However, the implementation of no-tillage has led to the formation of the "green bridge", i.e. the uninterrupted sequence of crops that benefits polyphagous pests (OLIVEIRA et al., 2014) such as the Fall armyworm, Spodoptera frugiperda (J. E. Smith, 1797) (Lepidoptera: Noctuidae). This insect is considered a key pest in maize, causing production losses of around 34\% (CRUZ, 1995).

Despite having maize as its preferred host, Pogue (2002) cites more than eighty species of $S$. frugiperda host plants, demonstrating the high adaptability of this insect in various plant species. Boregas et al. (2013) has reported the development of this species in several common host plants in Brazil. Thus, due to the high degree of polyphagia, a study on this insect pest as to its development on and adaptability to potential cover crops is necessary to support the choice of maize predecessor plants that are not hosts preferred by $S$. frugiperda.

In this study, we will test the hypothesis that among the cover plants used in central region of Minas there is at least one that is unfavorable to the biological development of $S$. frugiperda.

The aim of this study was to evaluate the biological variables (survival, biomass, development period, adaptation and damage) of the fall armyworm in cover crops, under laboratory and greenhouse conditions.

\section{MATERIAL AND METHODS}

\section{Laboratory bioassays}

To obtain the leaves used in feeding caterpillars, cover crops were sown in the experimental field of Embrapa Maize and Sorghum, Sete Lagoas - MG, located $19^{\circ} 28^{\prime} 30$ " latitude S, $44^{\circ} 15^{\prime} 08 \mathrm{~W}$ longitude and 732 meters above the sea level. The cover crops grown in the bioassays were the same used by Moreira et al. (2014) to the central region of Minas Gerais: sunflower (Helianthus annuus L. - Compositae), sunn hemp (Crotalaria juncea L. - Leguminosae), brachiaria [Urochloa decumbens (Stapf) - Poaceae], millet [Pennisetum americanum (L.) Leek var. ADR 500Poaceae], black oat (Avena stringosa Schreb. Poaceae) and white lupin (Lupinus albus L. Leguminosae). To obtain leaves at a suitable vegetative state, sowing in the field was conducted in four consecutive weeks. The leaves were collected 30 days after sowing. This same methodology was adopted to obtain the leaves of maize hybrid P30F35 (stage V5), considered the standard plant for $S$. frugiperda development.
After harvesting, the leaves were cut and placed in plastic $50 \mathrm{ml}$ cups, totaling 48 repetitions per host. The leaves were arranged in a whorl and replaced every 48 hours throughout the larval period. For dealing with different plants, we used a sufficient amount leaves to fill the cup and maintain adequate moisture for the insect development. For the larvae survival evaluation, two neonate larvae were placed per cup 48 hours after hatching, and after this period, one larva per cup was maintained. The cups were sealed with acrylic lids and stored in a controlled environment at a temperature of $25 \pm$ $2^{\circ} \mathrm{C}$ and relative humidity of $70 \pm 10 \%$.

The parameters evaluated were: larval survival, pre-imaginal survival, larval biomass at 11 days, pupa biomass, larval period, immature period. For determination of survival every four individuals was considered as a repetition. The experimental design was completely randomized and the data were subjected to analysis of variance and means were compared by Scott-Knot test at $5 \%$ probability.

The cover crops were analyzed comparatively, using the Adaptation Index (AI) proposed by Boregas et al. (2013). To calculate the index the following formula was used:

\section{$\mathrm{AI}=\mathrm{LS}(\%) * \mathrm{FDA} / \mathrm{LDP}$}

Where $\mathrm{AI}=$ adaptation index, $\mathrm{LS}=$ larval survival, FDA = fecundity of adults and LDP = larval development period. To determine this index the fecundity parameter was replaced by pupal biomass, for presenting correlating.

After calculated of adaptation index, the Relative Adaptation Index (RAI) was found, which is the ratio between the $\mathrm{AI}$ of an insect on a given host and $\mathrm{AI}$ on maize.

\section{$\mathrm{RAI}=100 *(\mathrm{AIc}) /(\mathrm{AIm})$}

Where AIc $=$ adaptation index of $S$. frugiperda on the cover crops, $\mathrm{AIm}=$ adaptation index of $S$. frugiperda on maize.

\section{Bioassay in greenhouse}

The experimental plot consisted of a 5L pot of soil containing four plants of each cover species. In this study, besides the species studied in the laboratory test, the Urochloa ruziziensis Germain \& Evrard cv - Poaceae and forage turnip (Rafanus sativus L. - Brassicaceae ) were used. Under the laboratory conditions, it was not possible to maintain the turgidity of these two plant species to determine biological aspects. Twenty-two days after planting, when the maize reached the V5 stage, each plant was infested with five newly-hatched $S$. frugiperda larvae from the laboratory colony. The damage evaluations were performed at 7, 14 and 21 days after infestation, using a grading scale from 0 
to 5, adapted from Carvalho (1970). A grade of zero corresponds to undamaged plants; Grade 1 to plants with scraped leaves; Grade 2 to plants with perforated leaves; Grade 3 to plants with partially destroyed leaves; Grade 4 to plants with only stems after the attack and Grade 5 corresponds to completely destroyed plants.

At 14 days after infestation half the number of pots of each treatment was withdrawn for the removal of larvae from soil and plants. These larvae were individually placed in $50 \mathrm{ml}$ plastic cups and sent to the laboratory for biomass determination. After 21 days of infestation, the same procedure was performed with the other pots, removing the pupae from the soil for biomass evaluation.

The greenhouse was maintained in a controlled environment at a temperature of $28 \pm 2{ }^{\circ} \mathrm{C}$ and relative humidity of $50 \pm 10 \%$

The experimental design was completely randomized with ten replicates and the larvae and pupae biomass accumulation data was subjected to analysis of variance and means were compared by Scott-Knot test at $5 \%$ probability.
Cover plants were analyzed comparatively, using the Adaptation Index (AI) and Relative Adaptation Index (RAI), as described earlier for lab results.

To determine this index the fecundity parameter was replaced by pupal biomass at 21 days.

Simultaneously, samples of field-grown cover crops were collected to perform bromatological analysis using the combustion method of Dumas for determination of nitrogen (SADER et al., 2004).

\section{RESULTS AND DISCUSSION}

\section{Laboratory bioassays}

Larval survival of $S$. frugiperda was lower in the cover crops: $U$. decumbens, millet, white lupin and sunn hemp with a mean survival of $69 \%$ (Table 1). On the other hand, oat maize and sunflower plants stood as those that provided higher average survival rate of the larvae (89\%).

Table 1. Survival (\%) of Spodoptera frugiperda fed on six cover crops and maize during the larval and preimaginal stages under laboratory conditions at $25 \pm 2{ }^{\circ} \mathrm{C}, 70 \% \mathrm{RH}$.

\begin{tabular}{lcc}
\hline Cover crops & Larval stage survival & Pre-imaginal stage survival \\
\hline Oats & $83.33 \pm 5.61 \mathrm{a}$ & $64.58 \pm 6.49 \mathrm{a}$ \\
B. decumbens & $72.91 \pm 7.18 \mathrm{~b}$ & $45.83 \pm 7.43 \mathrm{~b}$ \\
Millet & $77.08 \pm 4.82 \mathrm{~b}$ & $58.33 \pm 7.74 \mathrm{~b}$ \\
Maize & $90.00 \pm 3.27 \mathrm{a}$ & $81.66 \pm 3.83 \mathrm{a}$ \\
White lupin & $57.69 \pm 6.56 \mathrm{~b}$ & $51.92 \pm 7.73 \mathrm{~b}$ \\
Sunflower & $93.75 \pm 3.26 \mathrm{a}$ & $56.25 \pm 9.29 \mathrm{~b}$ \\
Sunn hemp & $70.83 \pm 7.43 \mathrm{~b}$ & $68.75 \pm 6.96 \mathrm{a}$ \\
\hline
\end{tabular}

The survival rate of the $S$. frugiperda preimaginal stage on $U$. decumbens plants, millet, white lupin and sunflower was low (53\%). Maize was the host that provided the highest percentage of pupal survival (81.6).

Among the cover crops evaluated, sun hemp was found to provide the lowest larval biomass (158.59 $\pm 15.69 \mathrm{mg}$ ) (Table 2). On white lupin and sunflower S. frugiperda showed higher biomass $(552 \mathrm{mg})$. According to Sá et al. (2009), usually the larvae accumulate biomass until the beginning of the pre-pupa period while feeding, but end up spending a lot of energy to reach the pupal stage. Thus, hosts that lead insects to accumulate less biomass up to the pre-pupa stage can be considered less appropriate for their development.

The larval period of $S$. frugiperda of 18.7 days on $U$. decumbens and sunn hemp was significantly higher than on other cover plants
(Table 2). For other hosts, the larval period was 16 days. According Boregas et al. (2013), usually the shortest larval period indicates greater suitability of the host for insect development since the faster the cycle is completed, the higher the number of generations. Sá et al. (2009) reported a larval period of 12 days for insects reared on maize, indicating it as the host preferred by $S$. frugiperda.

In this study, we verified that $S$. frugiperda showed lower larval biomass and increased larval period on sunn hemp, as well as lowest larval survival rates, indicating less suitability of this plant for insect development.

For pupal biomass, it was found that millet and maize resulted in lower values $(230 \mathrm{mg}$ ) (Table 2 ). The average biomass of pupae in the other cover crops was $268 \mathrm{mg}$. In general, pupal biomass is a parameter with low variability, as it is a phase of lower body water accumulation. Furthermore, 
according to Pencoe \& Martin (1981), there is a direct correlation between the pupal biomass and adult fertility, being that heavier pupae lead a larger proportion of fertile adults.

Table 2. Biomass of larvae and pupae larval and immature development period (mean \pm SE) of Spodoptera frugiperda caterpillars fed on leaves of six cover crops and maize in laboratory conditions at $25 \pm$ $2^{\circ} \mathrm{C}, 70 \% \mathrm{RH}$.

\begin{tabular}{lcccc}
\hline Cover crops & $\begin{array}{c}\text { Larval } \\
\text { Biomass (mg) }\end{array}$ & Pupal Biomass (mg) & $\begin{array}{c}\text { Larval } \\
\text { development } \\
\text { (days) }\end{array}$ & $\begin{array}{c}\text { Immature } \\
\text { development } \\
\text { (days) }\end{array}$ \\
\hline Oats & $454.42 \pm 27.28 \mathrm{~b}$ & $266.32 \pm 5.01 \mathrm{a}$ & $15.66 \pm 0.41 \mathrm{~d}$ & $25.00 \pm 0.39 \mathrm{c}$ \\
U. decumbens & $262.72 \pm 16.85 \mathrm{~d}$ & $266.01 \pm 6.85 \mathrm{a}$ & $18.00 \pm 0.22 \mathrm{~b}$ & $26.83 \pm 0.35 \mathrm{~b}$ \\
Millet & $343.09 \pm 18.84 \mathrm{c}$ & $225.34 \pm 5.91 \mathrm{c}$ & $16.69 \pm 0.44 \mathrm{c}$ & $26.03 \pm 0.33 \mathrm{~b}$ \\
Maize & $419.68 \pm 20.91 \mathrm{~b}$ & $235.90 \pm 4.38 \mathrm{c}$ & $16.70 \pm 0.28 \mathrm{c}$ & $26.43 \pm 0.20 \mathrm{~b}$ \\
White lupin & $585.07 \pm 17.44 \mathrm{a}$ & $283.65 \pm 8.23 \mathrm{a}$ & $15.65 \pm 0.16 \mathrm{~d}$ & $24.88 \pm 0.26 \mathrm{c}$ \\
Sunflower & $519.61 \pm 18.80 \mathrm{a}$ & $275.84 \pm 5.42 \mathrm{a}$ & $15.63 \pm 0.14 \mathrm{~d}$ & $24.72 \pm 0.22 \mathrm{c}$ \\
Sunn hemp & $158.59 \pm 15.70 \mathrm{e}$ & $252.25 \pm 4.14 \mathrm{~b}$ & $19.46 \pm 0.42 \mathrm{a}$ & $28.19 \pm 0.33 \mathrm{a}$ \\
\hline
\end{tabular}

* Means followed by the same letter in the column do not differ by Scott-Knot test at $5 \%$ probability.

The development period of the juvenile phase of $S$. frugiperda was highest in sunn hemp (28.2 days) (Table 2), as well as millet, maize and $B$. decumbens ( 26 days). The shortest immature phase duration was 24 days, on sunflower, white lupin and oats. In this case, is important to note that the longer the immature period of an individual, the longer the exposure to this external factors that can influence its survival. Furthermore, an insect that takes longer to complete the cycle is consequently exposed longer to biotic and abiotic factors of mortality and consequently has a smaller number of generations and thus lower host suitability (BOREGAS et al., 2013)

The S. frugiperda adaptation index was highest in sunflower $(\mathrm{AI}=1.61)($ Table 3$)$. oats $(\mathrm{AI}$ $=1.41)$ and maize $(\mathrm{AI}=1.24)$ and lowest in $U$. decumbens $(\mathrm{AI}=1.05)$, millet $(\mathrm{AI}=1.05)$, white lupin $(\mathrm{AI}=1.07)$ and sunn hemp $(\mathrm{AI}=0.90)$. Boregas et al. (2013) found higher rates for maize $(\mathrm{AI}=2.0)$ and millet $(\mathrm{AI}=1.7)$, that were the two species common to this work.

Table 3. Adaptation Index (AI) and Relative Adaptation Index (RAI) of Spodoptera frugiperda in cover crops tested in the laboratory and in the greenhouse.

\begin{tabular}{lccccccc}
\hline & \multicolumn{3}{c}{ Laboratory experiment } & \multicolumn{3}{c}{ Greenhouse experiment } \\
\hline Cover crops & $\begin{array}{l}\text { Larval stage } \\
\text { survival }(\%)\end{array}$ & AI & RAI & $\begin{array}{l}\text { Larval stage } \\
\text { survival }(\%)\end{array}$ & AI & RAI \\
Oats & 83 & 1.41 & 114.45 & 55 & 0.48 & 77.58 \\
U. ruziziensis & - & - & - & 52 & 0.63 & 101.92 \\
U. decumbens & 72 & 1.05 & 85.18 & 56 & 0.63 & 100.98 \\
Millet & 77 & 1.05 & 84.90 & 62 & 0.76 & 123.40 \\
Maize & 90 & 1.24 & 100.00 & 58 & 0.62 & 100.00 \\
Turnip & - & - & - & 67 & 0.77 & 123.95 \\
White lupin & 57 & 1.07 & 86.46 & 47 & 0.52 & 83.51 \\
Sunflower & 93 & 1.61 & 130.28 & 38 & 0.45 & 73.34 \\
Sunn hemp & 70 & 0.90 & 72.85 & 44 & 0.39 & 62.59 \\
\hline
\end{tabular}

The relative adaptation index of $S$. frugiperda also followed the same previous pattern. Sunflower $($ RAI $=130.28 \%)$ and oats $(\mathrm{RAI}=$ $114.45 \%)$ showed the highest levels unlike $B$. decumbens $(\mathrm{RAI}=85.18 \%)$, millet $(\mathrm{RAI}=84.90 \%)$, white lupin $(\mathrm{RAI}=86.46 \%)$ and sunn hemp $(\mathrm{RAI}=$ 72.85\%) (Table 3).

According to Marschner (1995), selection of the insect for a given host can be influenced by nutrient availability, since it alters the chemical composition and morphology with the development of the plant.

\section{Bioassays in greenhouse}

When kept on sunn hemp, S. frugiperda had the lowest biomass at 14 days $(213.14 \pm 13.95 \mathrm{mg})$ (Table 4). However, at 21 days, the $S$. frugiperda biomass was lower on sunn hemp and oats, 185 and $183 \mathrm{mg}$, respectively. It should be stated, however, that at 14 days under the same experimental 
conditions, this pest species fed on the entire oat plant. Thus, the reduced food availability may have accelerated the development of insects that entered the pupal stage, leading to the finding of lower values for this variable. In the other cover crops the biomass was higher, being that on white lupin, maize, $U$. decumbens and turnip the average biomass was $232 \mathrm{mg}$, different from sunflower, millet and $U$. ruziziensis, with $254.9 \mathrm{mg}$. Meagher et al. (2004) also found lower biomass accumulation for $S$. frugiperda kept on sunn hemp corroborating the data found herein.

Larval survival of $S$. frugiperda at 14 days was around 50\% (Table 4), regardless of the host plant. At 21 days, on sunn hemp, S. frugiperda had the lowest pupal survival (7\%) followed by white lupin, sunflower and oats (32.6\%). On millet, turnip, maize and $U$. decumbens, pupal survival was $66.7 \%$, and $U$. ruziziensis stood out as the cover crop that resulted in the highest pupal survival $(91 \pm 2.91 \%)$.

Table 4. Biomass and survival (\%) at 14 and 21 days (mean \pm SE) of Spodoptera frugiperda fed on leaves of eight cover crops and maize under greenhouse conditions.

\begin{tabular}{lcccc}
\hline \multicolumn{1}{c}{ Cover crops } & $\begin{array}{c}\text { Biomass at 14 } \\
\text { days }(\mathrm{mg})\end{array}$ & $\begin{array}{c}\text { Biomass at 21 days } \\
(\mathrm{mg})\end{array}$ & $\begin{array}{c}\text { Survival at 14 } \\
\text { days }(\%)\end{array}$ & $\begin{array}{c}\text { Survival at } 21 \\
\text { days }(\%)\end{array}$ \\
\hline Oats & $358.76 \pm 16.35 \mathrm{~b}$ & $183.45 \pm 7.48 \mathrm{c}$ & $55 \pm 10.95 \mathrm{a}$ & $40 \pm 04.47 \mathrm{c}$ \\
U. ruziziensis & $467.68 \pm 22.96 \mathrm{a}$ & $254.91 \pm 2.76 \mathrm{a}$ & $52 \pm 11.68 \mathrm{a}$ & $91 \pm 02.92 \mathrm{a}$ \\
U. decumbens & $418.31 \pm 17.67 \mathrm{a}$ & $234.52 \pm 3.49 \mathrm{~b}$ & $56 \pm 10.08 \mathrm{a}$ & $70 \pm 05.48 \mathrm{~b}$ \\
Millet & $401.99 \pm 17.62 \mathrm{a}$ & $258.87 \pm 4.84 \mathrm{a}$ & $62 \pm 4.90 \mathrm{a}$ & $53 \pm 13.00 \mathrm{~b}$ \\
Maize & $389.21 \pm 20.50 \mathrm{~b}$ & $224.14 \pm 4.20 \mathrm{~b}$ & $58 \pm 7.18 \mathrm{a}$ & $70 \pm 04.18 \mathrm{~b}$ \\
Turnip & $356.10 \pm 18.14 \mathrm{~b}$ & $240.60 \pm 4.15 \mathrm{~b}$ & $67 \pm 6.04 \mathrm{a}$ & $74 \pm 07.31 \mathrm{~b}$ \\
White lupin & $330.34 \pm 24.73 \mathrm{~b}$ & $231.36 \pm 11.87 \mathrm{~b}$ & $47 \pm 9.43 \mathrm{a}$ & $25 \pm 07.12 \mathrm{c}$ \\
Sunflower & $341.92 \pm 33.27 \mathrm{~b}$ & $251.03 \pm 6.12 \mathrm{a}$ & $38 \pm 4.19 \mathrm{a}$ & $33 \pm 02.98 \mathrm{c}$ \\
Sunn hemp & $213.14 \pm 13.95 \mathrm{c}$ & $185.01 \pm 14.74 \mathrm{c}$ & $44 \pm 9.67 \mathrm{a}$ & $07 \pm 03.00 \mathrm{~d}$ \\
\hline
\end{tabular}

* Means followed by the same letter in the column do not differ by Scott-Knot test at $5 \%$ probability.

Regarding the degree of damage, maize and millet had leaves partially destroyed in all phases of evaluation (Figure 1). U. ruziziensis, sunflower and turnip had pierced leaves the first two evaluations and partially destroyed leaves in the last assessment. For $U$. decumbens, pierced leaves were observed on the seventh day and partially destroyed leaves in subsequent evaluations. On white lupin, leaves were pierced in the first damage assessment and consecutive increase in damage in the following evaluations. Oats was the cover crop preferred by $S$. frugiperda for feeding, with the damage progress at each evaluation, being the only crop that presented completely destroyed plants after 21 days.

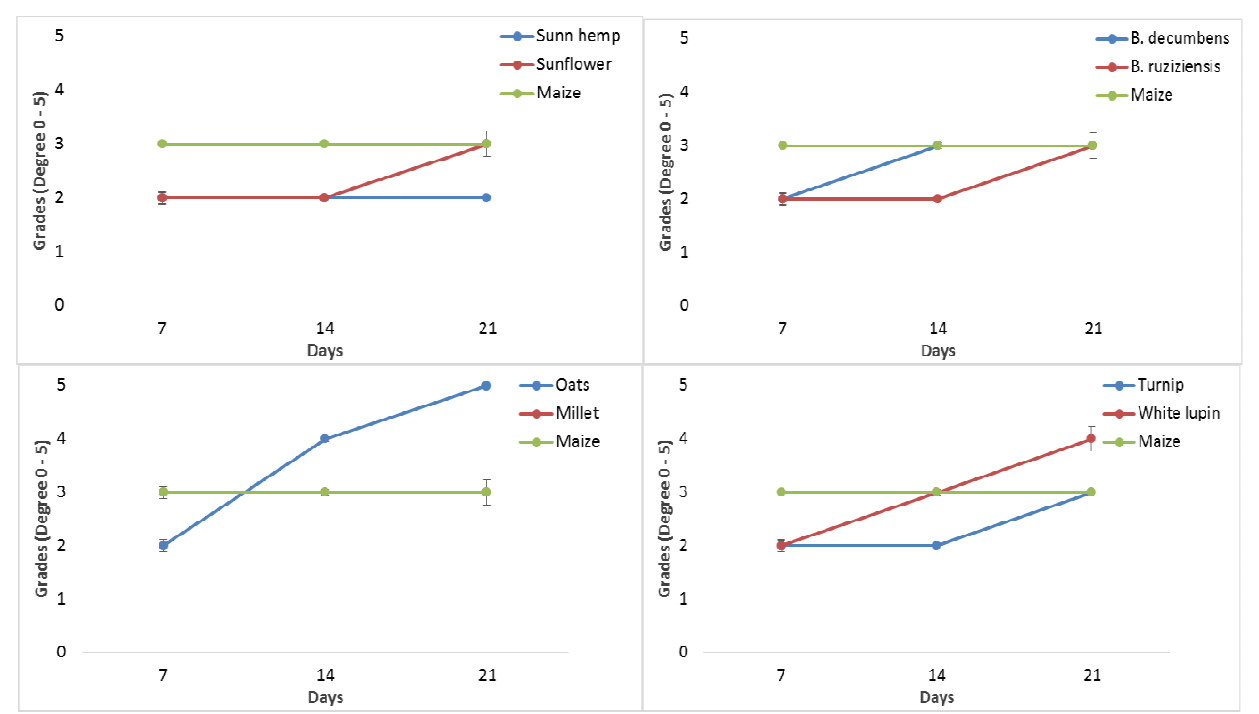

Figure 1. Degree of damage (damage grades ranging from 0-5) $( \pm \mathrm{CI}, \mathrm{p}=0.005)$ at 7, 14 and 21 days in eight cover crops and maize, infested with Spodoptera frugiperda in a greenhouse. 
On the other hand, sunn hemp showed the lowest susceptibility in relation to leaf damage caused by $S$. frugiperda, with a predominance of pierced leaves in all evaluations, which can be explained by lowest insect survival on this host.

The grasses were generally more favorable to the development of $S$. frugiperda in the greenhouse, although their bromatological analysis indicated less nitrogen compared to those broadleaf hosts evaluated in this study (Table 5). It is noteworthy that the biology of the insect is strongly affected by food source offered, altering its
DIAS, A. S. et al.

performance in response to physical, chemical and biological characteristics of the food eaten, as well as the interactions of these foods with biotic and abiotic factors of the agro ecosystem. Among the constituent elements of plants, nitrogen is described as the most important from an insect nutrition point of view, playing a key role in all metabolic processes and genetic coding (PANIZZI; PARRA, 2009). In terms of available quantity and quality, nitrogen usually limits the growth and fecundity of insects.

Table 5. Bromatologic analysis of cover crops.

\begin{tabular}{lc}
\hline Cover crops & Nitrogen content (\%) \\
\hline Oats & 4.18 \\
U. ruziziensis & 2.41 \\
U. decumbens & 3.66 \\
Millet & 3.16 \\
Maize & 6.12 \\
Turnip & 6.56 \\
White lupin & 6.13 \\
Sunflower & 5.27 \\
\hline
\end{tabular}

According to Veenstra et al. (1995), the host plant has a significant effect on many biological variables of $S$. frugiperda, including the larval biomass, the larval period and pupal biomass. The results indicate that in sunn hemp, S. frugiperda showed less adaptability to the bio-ecological parameters evaluated. In this work, it was apparent the negative influence of sunn hemp when provided to $S$. frugiperda. This influence was found due to lower larval biomass, longer duration of the larval stage in the laboratory and lower biomass at 21 days in the greenhouse. Allied to this data, sunn hemp plants showed the least damage in the greenhouse. McSorley et al. (2009) found that factors such as the architecture of the branches and the density of the sunn hemp, associated with increased humidity and temperature reduction, favor areas of refuge and shelter for parasitoids and predators.

Although field studies could be conducted to validate the indications found here, the data presented in this study is consistent with those of McSorley et al. (2008), who showed that sunn hemp plays a significant role in Integrated Pest Management programs. As such, it can be used in crop systems to attract or repel pests, natural enemies and other organisms (SANTOS et al., 2008).

The results obtained in the laboratory and greenhouse bioassays suggest, respectively, that chemical and morphological characteristics of cover crops can influence the survival and development of $S$. frugiperda. The chemical factors can be evaluated especially regarding nutritional composition of each plant and the morphological factors are related to plant architecture. The latter proved to be one of the possible variables that influenced the development of the insect, since the amount and insertion of the leaves interfere, facilitating or harming feeding, egg laying and pest protection against natural enemies. This factor may explain the increased damage observed in oats, that has the highest leaf density and arrangement in the greenhouse, in contrast to less damage observed in sunn hemp.

Literature data indicate that the leaves of grasses form a whorl, a favorite feeding site of $S$. frugiperda (BOREGAS, 2009). Furthermore, relative adaptation index of $S$. frugiperda, better in the grasses, indicates that these plants are more favorable for insect development.

The adaptation index of $S$. frugiperda was higher in turnip $(\mathrm{AI}=0.77)$ and millet $(\mathrm{AI}=0.76)$ and lower in sunn hemp (AI = 0.39) (Table 3). Following the same previous pattern, the relative adaptation index of $S$. frugiperda in turnip (RAI = $123.95 \%)$, millet $(\mathrm{RAI}=123.4 \%)$ and lower in sunn hemp $(\mathrm{RAI}=62.59 \%)$.

Both in the laboratory and in the greenhouse, the sunn hemp was the plant that showed the lowest adaptation index and consequently, the lowest relative adaptation. 
However, laboratory tests indicate only the food quality of the substrate, as the plant is in a state of lower turgidity compared conditions in the field. As such, the results with for turnip and $U$. ruziziensis obtained in the laboratory were not used because of the inability to maintain a turgid state. However, in the greenhouse it is also possible to evaluate the effect of plant architecture on $S$. frugiperda, although the result closest to the real would be that obtained in the field.

Taking into consideration health criteria for selecting a plant that avoids formation of the "green bridge" and enables its use as a forerunner to maize in no-till cultivation, reducing the incidence of $S$. frugiperda in the area, $C$. juncea stood out as the cover crop less susceptible to pest development and damage.

\section{CONCLUSION}

For the biological parameters of $S$. frugiperda evaluated, C. juncea is less suitable as its food and for its development and therefore has potential use as a cover crop to maize in the notillage system.

\section{ACKNOWLEDGMENTS}

To Fapemig for granting the scientific initiation scholarship. To the University Center of Sete Lagoas - UNIFEMM, and Embrapa Maize and Sorghum for their support in carrying out the work.

RESUMO: O objetivo do trabalho foi avaliar variáveis biológicas de Spodoptera frugiperda (J.E. Smith, 1757) em espécies de plantas de cobertura. Os ensaios foram conduzidos em laboratório e casa de vegetação. Foram utilizadas as seguintes espécies: girassol (Helianthus annuus), crotalária (Crotalaria juncea), brachiaria (Urochloa decumbens e Urochloa ruziziensis), milheto (Pennisetum americanum), aveia preta (Avena stringosa), tremoço (Lupinus albus), nabo forrageiro (Rafanus sativus) e milho (Zea mays). Em laboratório, a sobrevivência larval de S. frugiperda variou de $57 \%$ em L. albus a $93 \%$ em H. annuus e a sobrevivência da fase pré-imaginal de $45 \%$ em U. decumbens a $81 \%$ no milho. Em $C$. juncea, a biomassa larval de $S$. frugiperda foi menor e o período de desenvolvimento da fase jovem e larval maior. O índice de adaptação foi menor em $C$. juncea em casa de vegetação e laboratório. Em casa de vegetação, a sobrevivência larval, aos 14 dias, foi similar em todas as plantas e, aos 21 dias, menor em C. juncea. Houve menor acúmulo de biomassa, aos 14 dias, em $C$. juncea e, aos 21 dias, em $C$. juncea e A. stringosa. Quanto à injúria, $C$. juncea apresentou menor susceptibilidade ao ataque de $S$. frugiperda. Os resultados indicam $C$. juncea como planta promissora para cobertura do solo antecedendo a cultura do milho.

PALAVRAS-CHAVE: Plantas de Cobertura . Lagarta-do-cartucho. Plantio direto. Zea mays.

\section{REFERENCES}

ALVARENGA, R. C.; CABEZAS, W. A. L.; CRUZ, J. C.; SANTANA, D. P. Plantas de cobertura de solo para sistema plantio direto. Informe Agropecuário, Belo Horizonte, v. 22, n. 208, p. 25-36, jan/fev. 2001.

ANDRIOLI, I.; BEUTLER, A. N.; CENTURION, J. F.; ANDRIOLI, F. F.; COUTINHO, E. L. M. Produção de milho em plantio direto com adubação nitrogenada e cobertura do solo na pré-safra. Revista Brasileira de Ciência do Solo, Viçosa, v. 32, n. 4, p. 1691-1698, mai. 2008 http://dx.doi.org/10.1590/S010006832008000400034

AZIZ, I.; MAHMOOD, T.; ISLAM, K. R. Effect of long term no-till and conventional tillage practices on soil quality. Soil and Tillage Research, Amsterdam, v. 131, p. 28-35, jul. 2013. doi:10.1016/j.still.2013.03.002

BARROS, E. M.; TORRES, J. B.; RUBERSON. J. R.; OLIVEIRA, M. D. Development of Spodoptera frugiperda on different hosts and damage to reproductive structures in cotton. Entomologia Experimentalis et Applicata, Dordrecht, v. 137, n. 3, p. 237-245, aug. 2010. http://onlinelibrary.wiley.com/doi/10.1111/j.15707458.2010.01058.x/epdf 
BOER, C. A.; ASSIS, R. L.; SILVA, G. P.; BRAZ, A. J. B. P.; BARROSO, A. L. L.; CARGNELUTTI FILHO, PIRES, F. R. Ciclagem de nutrientes por plantas de cobertura na entressafra de um solo de cerrado. Pesquisa Agropecuária Brasileira, Brasília, v. 42, n. 9. p. 1269-1276, set. 2007. http://dx.doi.org/10.1590/S0100204X2007000900008

BOREGAS, K. G. B. Performance Diferencial de Spodoptera frugiperda (JE Smith, 1797) (Lepidoptera: Noctuidae) em Hospedeiros Alternativos. 2009. 73p. Tese (Doutorado) - Universidade Federal de Minas Gerais, Belo Horizonte.

BOREGAS, K. G. B.; MENDES, S. M.; WAQUIL, J. M.; WILSON, G. Estádio de adaptação de Spodoptera frugiperda (J.E. Smith, 1797) (Lepidoptera: Noctuidae) em hospedeiros alternativos. Bragantia, Campinas, v. 72, n. 1, p. 61-70, abr. 2013. http://dx.doi.org/10.1590/S0006-87052013000100009

CARVALHO, R. P. L. Danos, flutuação da população, controle e comportamento de Spodoptera frugiperda (J.E. Smith, 1797) e susceptibilidade de diferentes genótipos de milho, em condições de campo. 1970. 170p. Tese (Doutorado) - Escola Superior de Agricultura Luiz de Queiroz - Universidade de São Paulo, Piracicaba.

CRUZ, I. A lagarta-do-cartucho na cultura do milho. Sete Lagoas: Embrapa-CNPMS, 1995. 45 p. (Circular técnica, 21). https://www.infoteca.cnptia.embrapa.br/infoteca/handle/doc/475779

CRUZ, J. C. No plantio direto o milho é o melhor. Cultivar, Pelotas, v. 1, n. 8, p. 28-29, set. 1999.

FALEIROS, G. SEMEANDO SUSTENTABILIDADE. Colaboração Brasil Reino Unido sobre Agricultura de Baixo Carbono. Brasília, DF: Embaixada Britânica, 2011, 45p.

http://www.agricultura.gov.br/arq_editor/file/Sala\%20de\%20Imprensa/Publica\%C3\%A7\%C3\%B5es/SEMEA NDO\%20SUSTENTABILIDADE.pdf

MARCHÃO, R. L. Integração lavoura-pecuária num Latossolo do Cerrado: impacto na física, matéria orgânica e macrofauna. 2007. 153p. Tese (Doutorado) - Universidade Federal de Goiás, Goiânia.

MARSCHNER, H. Mineral nutrition of higherplants. San Diego: Academic, 1995. 889 p.

MCSORLEY, R.; SEAL, D. R.; KLASSEN, W.; WANG, K. H.; HOOKS, C. R. R. Non-target effects of sunn hemp and marigold cover crops on the soil invertebrate community. Nematropica, Florida, v. 39, n. 2, p. 235 245, dec. 2009. http://journals.fcla.edu/nematropica/article/view/64483

MCSORLEY, R.; WANG, K. H.; FREDERICK, J. J. Integrated effects of solarization, sunn hemp cover crop, and amendment on nematodes, weeds, and pepper yields. Nematropica, Florida, v. 38, n. 2, p. 115-125, dec. 2008. http://journals.fcla.edu/nematropica/article/view/64455

MEAGHER, R. L.; NAGOSHI, R. N.; STUHL, C.; MITCHELL, E. R. Larval development off all army worm (Lepidoptera: Noctuidae) on diferent cover crop plants. Florida Entomologist, Florida, v. 87, n. 4, p. 454-460, dec. 2004. http://dx.doi.org/10.1653/0015-4040(2004)087[0454:LDOFAL]2.0.CO;2

MOREIRA, S. G.; LUPP, R. M.; LIMA, C. G.; MARUCCI, R. C.; RESENDE, A. V.; BORGES, I. D. Massa Seca e Macronutrientes Acumulados em Plantas de Milho, Cultivadas sob Diferentes Espécies de Cobertura. Revista Brasileira de Milho e Sorgo, Sete lagoas, v. 13, n. 2, p. 218 - 231, ago. 2014.

http://rbms.cnpms.embrapa.br/index.php/ojs/article/view/460/pdf_88

NUNES, U. R.; ANDRADE JÚNIOR, V. C. A.; SILVA, E. B.; SANTOS, N. F.; COSTA, H. A. O.; FEREIRA, C. A. Produção de palhada de plantas de cobertura e rendimento do feijão em plantio direto. Pesquisa

Agropecuária Brasileira, Brasília, v. 41, n. 6, p. 943-948, jun. 2006. http://www.scielo.br/pdf/pab/v41n6/30858.pdf S0100-204X2006000600007 
OLIVEIRA, C. M.; AUAD, A. M.; MENDES, S. M.; FRIZZAS, M. R. (2014). Crop losses and the economic impact of insect pests on Brazilian agriculture. Crop Protection, Guildford, v. 56, p. 50-54, feb. 2014. http://www.sciencedirect.com/science/article/pii/S026121941300269X DOI: 10.1016/0167-8809(83)90038-5

PANIZZI, A. R.; PARRA, J. R. P. Bioecologia e nutrição de insetos: bases para o manejo integrado de pragas. Londrina: Embrapa Soja; Brasília, Embrapa Informação Tecnológica, 2009. 1164 p.

PENCOE, N. L.; MARTIN, P. B. Development and reproduction of fall armyworms on several wild grasses. Environmental Entomology, College Park, v. 10, n. 6, p. 999-1002, dec. 1981. http://dx.doi.org/10.1093/ee/10.6.999

POGUE, G. M.; A world revision of the genus Spodoptera Guenée (Lepidoptera: Noctuidae). Memoirs of the American Entomological Society, Philadelphia, v. 43, n. 28, p. 1-202. jan. 2002.

http://www.biodiversitylibrary.org/item/118237\#page/9/mode/1up

SÁ, V. G. M.; FONSECA, B. V. C.; BOREGAS, K. G. B.; WAQUIL, J. M. Sobrevivência e desenvolvimento larval de Spodoptera frugiperda (J. E. Smith, 1797) (Lepidoptera: Noctuidae) em hospedeiros alternativos. Neotropical Entomology, Londrina, v. 38, n. 1, p. 108-115, fev. 2009. http://dx.doi.org/10.1590/S1519566X2009000100012

SADER, A. P. O.; OLIVEIRA, S. G.; BERCHIELLI, T. T. Application of kjeldahl and dumas combustion methods for nitrogen analysis. Archives of Veterinary Science, Curitiba, v. 9, n. 2, p. 73-79, out. 2004. : http://dx.doi.org/10.5380/avs.v9i2.4068

SANTOS, G. G.; SILVEIRA, P. M. D.; MARCHÃO, R. L.; BÉCQUER, T.; BALBINO, L. C. Soil macrofauna communities and cover crops in a Cerrado Oxisolunder no tillage. Pesquisa Agropecuária Brasileira, Brasília, v. 43, n. 1, p. 115-122, jan. 2008. http://dx.doi.org/10.1590/S0100-204X2008000100015

SILVA, R. F.; TOMAZI, M.; PEZARICO, C. R.; AQUINO, A. M.; MERCANTE, F. M. Macrofauna invertebrada edáfica em cultivo de mandioca sob sistemas de cobertura do solo. Pesquisa Agropecuária Brasileira, Brasília, v. 42, n. 6, p. 865-871, jun. 2007. http://www.scielo.br/pdf/pab/v42n6/v42n6a14.pdf DOI: 10.4025/actasciagron.v30i5.5974

VEENSTRA, K.H.; PASHLEY, D.P.; OTTEA, J.A. Host-plant adaptation in fall armyworm host strains: comparison food consumption, utilization, and de toxication enzyme activities. Annals of the Entomological Society of America, College Park, v.88, n. 1, p. 80-91, jan. 1995. http://dx.doi.org/10.1093/aesa/88.1.80 